\title{
Books
}

\section{Recently Published Books}

Liz Henty and Daniel Brown (eds), Visualising Skyscapes: Material Forms of Cultural Engagement with the Heavens

Published by: Routledge

Year of Publication: 2019, ISBN: 9781138303614

Hardback, 296 pages, 69 colour illustrations, 15 b/w illustrations, £115.00

E-book: £36.00, ISBN: 9780203730935

Jillian Huntley and George Nash (eds), Aesthetics, Applications, Artistry and Anarchy: Essays in Prehistoric and Contemporary Art. A Festschrift in Honour of John Kay Clegg, 11 January 1935 - 1 March 2015

Published by: Archaeopress

Year of Publication: 2019, ISBN: 9781784919986

Paperback, $205 \times 290$ mm; viii+170 pages; 100 figures, 5 tables, 42 colour plates, $£ 35.00$

Andrew Meirion Jones and Marta Díaz-Guardamino, Making a Mark: Image and Process in Neolithic Britain and Ireland

Published by: Oxbow Books

Year of Publication: 2019, ISBN: 9781789251883

Paperback, $246 \times 185 \mathrm{~mm}, 320$ pages, over 100 colour and b/w photographs, $£ 40.00$

Patrick Vinton Kirch and Clive Ruggles, Heiau, 'Ina, Lani: The Hawaiian Temple System in Ancient Kahikinui and Kaup, Maui

Published by: University of Hawaii Press

Year of Publication: 2019, ISBN: 9780824878276

Hardback, 480 pages, 138 b/w illustrations, £82.50

\section{Forthcoming Books}

Gian Franco Chiai and Ralph Haeussler (eds), Sacred Landscapes

Published by: Oxbow Books

ISBN: 9781789253276

Hardback, 360 pages, b/w illustrations. Pre-order special price $£ 52.00$ 
John Kelly and James A. Brown, Cahokia: City of the Cosmos

Published by: Oxbow Books

ISBN: 9781785708855

Paperback, 256 pages, $246 \times 189 \mathrm{~mm}$, b/w and colour. Pre-order special price $£ 28.50$

Chris Scarre (ed.) Megalithic Tombs in Western Iberia

Published by: Oxbow Books

ISBN: 9781785709807

Hardback, 208 pages, b/w illustrations. Pre-order special price $£ 33.75$

Fabio Silva, Towards Skyscape Archaeology

Published by: Oxbow Books. Series: Oxbow Insights in Archaeology ISBN: 9781782979555

Paperback, 35 b/w illustrations, $£ 15.99$ 